Los Angeles), William A. Hance (Columbia University) and Vernon McKay (School of Advanced International Studies, Johns Hopkins University).

[Communicated by A. H. M. Kirk-Greene]

\title{
Annual Meeting of the American Anthropological Association
}

Ar the fifty-seventh annual meeting of the American Anthropological Association, held in Washington D.C. at the end of November 1958 , which was attended by nearly $1,000 \mathrm{mem}-$ bers, one session was set aside for Africa. Papers were read by William B. Schwab (Temple University), 'Conflict and Urbanization in an African Community'; Councill Taylor (U.C.L.A.), 'Yalunka Resistance to Urbanization'; Ronald Cohen (Toronto), 'Marriage Instability and its Determinants among the Kanuri of Northern Nigeria'; and Robert LeVine (Northwestern), 'Rape, Bridewealth, and Clanship in Gusii Society'.

In addition, a number of papers of African interest were presented at other sessions of the congress. These included 'Problems in Studying Ptimitive and Changing Economies', by Paul Bohannan (Princeton); 'The Effects of Labour Migration on Mossi Society', by Elliot P. Skinner (Columbia); 'The Impact of the Christian Concept of Forgiveness on an African System of Morality', by John Messenger (Michigan State); and papers in a symposium on ' Religious and Philosophical Beliefs in Relation to Socio-Economic Structure', by Robert G. Armstrong (Atlanta) for West Africa, and May Mandelbaum Edel (New School for Social Research) for East Africa.

\section{[Communicated by A. H. M. Kirk-Greene]}

\section{The United States and Africa-Meeting of the Rocky Mountain Assembly}

THE Rocky Mountain Assembly, sponsored by the Social Science Foundation of the University of Denver and the American Assembly, Columbia University, met in October at Glenwood Springs, Colorado. American political, economic, social, and cultural relationships with the countries of Africa were discussed during a three-day conference, and addresses were given by George $\mathrm{D}$. LaMont, Deputy Director of the Office of Middle and South African Affairs of the Department of State, and Sir Andrew Cohen, Permanent United Kingdom Representative on the Trusteeship Council of the United Nations and a former Governor of Uganda. Both speakers stressed the importance of economic aid and technical assistance for the rapidly developing African states and it was recognized that the United States government could make a particularly effective contribution by supporting university, technical, and vocational education, and teacher-training programmes which would help to alleviate some of the most critical shortages in the African educational field. Sir Andrew Cohen emphasized the need for more trained research workers in Africa. Research was nonpolitical and its results were of interest to the whole world; it was therefore a peculiarly suitable field for outside assistance to Africa.

\section{The Center of African Studies at the New School for Social Research, New York}

A CENTER of African Studies has recently been opened at the New School for Social Research in New York. The Director is Professor Sanford Griffith, who is in special charge of discussions on African problems, and the members of the advisory committee are Dr. William O. Brown, Dr. Vernon McKay, and Dr. Heinrich Wieschhoff. During the autumn of r9s 8 courses were given by S. and J. Comhaire-Sylvain on Black Africa's Larger Cities, by A. Melamid on African Geography, and by W. B. Schwab on Africa in Transition. Symposia on new careers for Africans were conducted by W. Dillon, in co-operation with the Phelps-Stokes Fund. 